\title{
SCHEDULLING MODEL OF REPLENISHMENT AT SEA FOR STRICKING FORCE UNIT IN SEA OPERATION USING GENETIC ALGORITHM
}

\author{
Aris Tri lka $\mathrm{R}^{1}$, Benny Sukandari ${ }^{2}$, Okol Sri Suharyo ${ }^{3}$, Ayip Rivai Prabowo ${ }^{4}$ \\ 1,2,3,4 Indonesian Naval Technology College, \\ STTAL-Bumimoro-Morokrembangan, Surabaya 60187, Indonesia
}

\begin{abstract}
Navy as a marine core in the defense force is responsible to providing security for realizing stability and security of the country. At any time there was invasion of other countries past through sea, TNI AL must be able to break the enemy resistance line through a sea operation to obtain the sea superiority. But this time the endurance of Stricking force Unit at only 7-10 days and required replenishment at sea to maximize the presence in the theater of operations to meet a demand of the logistics: HSD, Freshwater, Lubricating Oil, foodstuffs and amonisi. For the optimal replenishment at sea required scheduling model supporting unit to get the minimum time stricking force unit was on node rendezvous. Replenishment at sea scheduling model for stricking force unit refers to the problems Vehicle routing problem with time windows using Genetic Algorithms. These wheel base used is roulete for reproduction, crossover and mutation of genes. Genetic algorithms have obtained optimum results in the shortest route provisioning scenario uses one supporting unit with total time of 6.89 days. In scenario two supproting unit with minimal time is 4.97 days. In scenario the changing of node replenishment Genetic Algorithm also get optimal time is 4.97 days with two supporting unit. Research continued by changing the parameters of the population, the probability of crossover and mutation that can affect the performance of the genetic algorithm to obtain the solution.
\end{abstract}

Keywords: Genetic Algorithm, Model Scheduling, Stricking Force unit.

\section{INTRODUCTION.}

Geographical Indonesia is very strategic because it is the world that is in the cross international traffic and can be a transit trade lane world. The State Indonesia also has the natural resources and abundant nonbiological so making interest other countries to be possesed the trade lanes and abundant natural resources.

Under these conditions, the territorial waters of the hot area which could trigger open conflict with neighboring countries divided into 4 parts. The first area is the Malaka strait. The second is the Natuna sea,
Third Lombok Strait and the Arafuru sea is still vulnerable human smuggling and illegal fishing and the fourth is area Ambalat are still very prone to conflict.

Any time the enemy invasion through sea, the Navy must be able to break the enemy resistance line with sea operation to obtain the sea superiority. The key to successful operational success of the battle is determined by the ability to continue and efficient logistics (Rutenberg and Allen, 1991).

Replenishment at sea have a high level of uncertainty so that changes that occur 
both routes, the loading, unloading and the amount of cargo and inventory to be transported into a thing that must be considered (Christiansen, 2011). For the scheduling and route determination is very important because it ensures every customer can be served.

Brown and charlyle research (2008), about the optimization work scheduling CLF in supporting logistics for 13 battle groups scattered throughout the world. The method used MIP with the help of software GAMS. In these studies did not use a bridgehead and not calculate the optimal route and service time replenishm.

Combination of MIP method and Genetic Algorithm has been applied on a container ship with a time deadline constraints in the pickup and delivery simultaneously (Karlatfis et al., 2009, Maras et al., 2013). Determination of the inventory of the company cement (Christiansen et al., 2011). VRP problems with combining MIP and heuristic methods variable neighborhood descent (VND) is used to inventory model in the delivery of fuel (Vidovic et al., 2013). Lenhart, (2006) review the scheduling CSS in implementing USMC logistics support to troops in combat zones with heuristic VRP.

The benefit of Genetic Algorithms is the number of variables that can be handled quite a lot and be able to utilize computer systems that implement parallel (Haupt, 2002). A genetic algorithm allows a population comprising many invidu, to evolve under selection rules that have been set into the stage that maximizes fitness (Santosa, 2011). In addition Genetic algorithms are very flexible and good enough to be combined with other methods (Syamsi, 2002). Genetic algorithms are also very good in finding the least cost and the shortest route. (Tan et al, 2001).

From the review of research shows that the model that has been studied the most minimal cost oriented by choosing the shortest route and fleet use. But in marine operations costs not accounted for in actual fact what is needed is the advantage can be obtained through existing resources.

For that is the focus of this research is "How to make a model of scheduling and optimum route supporting force unit in distributing aid to the logistical needs of each warship stricking force unit at sea operations so as to provide durability in the ocean,"

\section{MATERIAL/METHODOLOGY}

2.1. Replenishment At Sea.

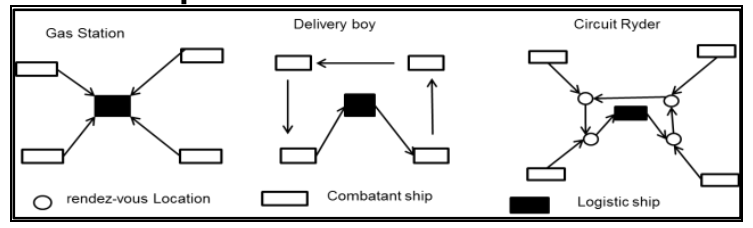

Figure 2.1. RAS Tactical

According to Dunn (1992), Tactics gas station is a tactic in conducting the RAS where the position of logistics ships were in the middle of the unit of time. Delivery boy tactics are tactics RAS where supply ships came to the ships that were carrying out patrols in the sector of duty. Taktik circuit rider, which is a combination gas station and delivery tactics boy where each combatant ships and boats supplay logistics given rendezvous node locations to implement RAS.

In this study, which will be the focus of the replenishment at sea is the provision of class I are both dry and wet food, provision of class 
III, namely HSD, Lube oil and fresh water and supplies class $V$ is ammunition.

\subsection{Prior research}

Gue (2003), create a model of the new concept with the USMC combat logistical support and accommodate the transportation from time to time, dynamic movement of troops as well as scheduling supplay. Lenhardt (2006), developed a model of optimization of the use of resources, asset and service network of the Combat Service Support (CSS) to USMC on the battlefield. The aim is to support the logistical needs such as water, fuel and ammunition for the Marines who were fighting. The concept of this model been applied in World War II and the cold war that the Marines excel in combat. According to Laporte (1992), Vehicle Routing Problem can be described as a problem in designing an optimal distribution route with branch and bound method, direct search tree, mixed integer programming, and heuristic column generation. Tan et al., (2001), Problems VRP time windows can use local search method is very simple but it is not able to resolve optimally. Simulated Annealing is the best in speed or compromising its performance due to a more systematic approach. Genetic Algorithms and Tabu search turned out to have a near-optimal solution best and highly effective in resolving the total cost of the smallest in all categories.

Nishi and Izuno (2014), to create a model to solve the problems of the assignment and scheduling of transport tankers carrying crude oil to the limited capacity of vessels using MIP algorithm combined with a column generation heuristic algorithms. Ho and Haugland (2004), examines the homogeneous fleet to determine the route through the vehicle routing and scheduling problem with time windows and split delivery (VRPTWSD). Hennig et al., (2014) compared the approach of two models of tankers carrying crude oil to solve the problem of scheduling and route determination to capture and separate delivery.

Christiansen et. al., (2011), reviewed the problems of Inventory Routing Problem in various cement products allocated to different port silos and minimize total transportation costs and can meet all the needs of customers on consumption harbor. Vidovic, M., et al (2013) made a model to solve the problems of inventory routing problem in the delivery of gasoline so that the cost of inventory and transportation costs can minimize the Variable Heuristic method neihbourhood Descent (VND). Al-Khayyal and Hwang, (2007), applying the compatibility issues and implement a dedicated compartement rules on ships for delivery of liquid chemicals from the factory to the port of the book. Mixed Integer Progamming method is proposed to solve the problems of inventory routing and scheduling problems of liquid bulk cargo ship in the taking then sends it to the entire island. Then Siswanto et.al. (2011) developed the problem of Al-khayyal and Hwang (2007) of dedicated compartement be undedicated compartment. The problems are route selection, the selection of the ship, the activity of loading and unloading activities by using the exact method MILP and one step greedy heuristic. Bronmo et al., (2007), making scheduling cargo ship bulk cargo at pickup and delivery with the proposed method is Progamming 
Linear, Mixed Integer Progamming combined with a column generation heuristic.

Bilgen and Ozkarahan, (2007), made a model of the problem mixing and delivery of products from manufacturers to port the port of consumers with different ship within 3 months of using MIP. Laporte et. al., (2010), examined the problems of vehicle routing problem at a car company that will hire a vessel to deliver a car to its customers with production and demand constraints are limited by the date of the contract with the customer. The method used is to model the problem into a Mixed Integer Programming.

Karlatfis et al., (2009), get a container ship routes services to perform retrieval and delivery to deadline time and solved by Genetic Encryption can be applied to a small container fleet in the Aegean Sea.

\subsection{Research Flowchart}

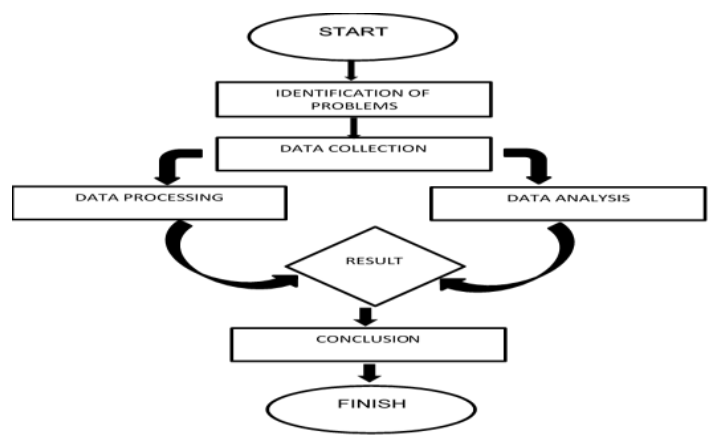

Figure 3.1. Research flowchart

\subsection{Sea Operation scenario.}

Country aggressor $\mathrm{X}$ has planned its invasion by sending additional aid forces, logistics and combat equipment to the armed separatist movements and forces ahead of them. Country $X$ purpose is to support the strategic plan for resource control Liquefied Natural Gas, oil refineries and coal in East Kalimantan region. Palawan Island has ruled previously and brigdehead developed as a base for military force to be moved to the South. Operational strength The strength of the enemy has the form 2 BCM Sea, 1 AT, 2 BU, 2 KS, 2 PKR, 2 PK, 2 KCR, 2 PR. PKR class and KCR equipped $\mathrm{C}-802$ missiles with a range $75 \mathrm{NM}$ and SAM missiles with a range 11 NM. Furthermore, Marine Operations carried out according to the scenario.

\subsection{Model Formulation}

a. Indices:

$W$ is available fleet supporting unit, $k$ is warship of supporting unit that will be able to replenishment at sea for each node $i, j$ and it is a belongs $W$, Node $i, j$ : is node of replenishment $\{1,2,3,4,5,6,7,8\}$ which place to wait replenishment of supporting unit $k, p$ is the depot for $k$ loading logistics. $C \mathrm{C}$ is a set of nodes replenishm consisting of $i, j, p$. $(i, j, p \in C)$

b. Decision Variable.

$X_{i j k}=1$, if supporting unit $k$ served node $j$ after served node $i,=0$, if otherwise, $t_{i}$ is time to wait atau time for striking force unit to replenish from supporting unit $k$ in node $i\{i=$ $1,2,3,4,5,6,7,8\}$ [hari]. $a_{i}$ is initial time to came from $i$ [day]

c. Constant variable

$d_{i, j}$ is distance from $i, j$ [day], $E_{k}$ is the cargo capacity from supporting unit [day] $E_{i}$ is demand commodity logistic in node $i$ and to constraint time windows for supporting unit replenishment [day]

d. Parameter

$s_{i k}$ is the necessary time to served replenishment in node $i$ by ship $k$ [day],

$t_{i j}$ is time to traverse arc $i$ to $j$ [day]

\section{The Objective function}


Minimize time to wait in rendezvous area and shortes route.

$$
\min \sum_{i=1}^{8} t_{i}
$$

\section{Constraint}

a. Ensure that every demand node is served by exactly one ship

$$
\begin{aligned}
& \sum_{i \in C} \sum_{j \in C} X_{i j k} \leq 1 \quad \forall j \in C \\
& \sum_{k \in W} X_{i j k} \leq 1
\end{aligned}
$$

b. Guarantess that a ship exits the demand node it enter

$$
\sum_{i \in C} X_{i p k}=\sum_{j \in C} X_{j p k} \quad \forall p \in C, k \in W
$$

c. Ship Capacity

$\sum_{i \in C} E_{i} \sum_{j \in C} X_{i j k} \leq E_{k} \quad \forall k \in W$

d. Handles maximum allowable travel time $\sum_{i \in C} s_{i k} \sum_{j \in C} X_{i j k}+\sum_{i \in C} \sum_{j \in C} t_{i j k} . X_{i j k} \leq T_{k} \forall k \in W$

e. Ensure that maximum available number of ship is not exceeded.

$$
\begin{gathered}
\sum_{j \in C} X_{0 j k} \leq 1 \quad \forall k \in W \\
\sum_{j \in C} X_{i 0 k} \leq 1 \quad \forall k \in W
\end{gathered}
$$

f. Ensure successive arrival times between ports $a_{j} \leq a_{i}+s_{i k}+t_{i j k}+\left(1-X_{i j k}\right) \quad \forall i, j \in C, k \in W(9)$

g. Restricts arrival times as time windows

$a_{j} \geq E_{j} \quad \forall j \in C$

$a_{0}=0$

\section{RESULT AND DISCUSSION}

\begin{tabular}{|c|c|c|c|c|c|c|c|}
\hline \multirow{2}{*}{ No } & \multirow{2}{*}{ Nama KRI } & \multirow{2}{*}{ Speed } & \multirow{2}{*}{$\begin{array}{l}\text { Range } \\
\text { (NM) }\end{array}$} & \multicolumn{4}{|c|}{ Kapasitas } \\
\hline & & & & \begin{tabular}{|l|} 
HSD (liter) \\
\end{tabular} & Makanan (kg) & Minyak Lumas (Itr) & Air Tawar (ltr) \\
\hline 1 & PKR-1 & 15 & 5,000 & 557,650 & 7,851 & $\begin{array}{r}9,165 \\
\end{array}$ & 33,500 \\
\hline 2 & PKR-2 & 15 & 5,000 & 557,650 & 7,851 & 9,165 & 33,500 \\
\hline 4 & PKR-3 & 15 & 5,000 & 557,650 & 7,851 & 9,165 & 33,500 \\
\hline 5 & PKR-4 & 16 & 4,000 & 200,000 & 4,000 & 14,000 & 55,000 \\
\hline 6 & PKR-5 & 16 & 4,000 & 200,000 & 4,000 & 14,000 & 55,000 \\
\hline 7 & PKR-6 & 18 & 4,000 & 218,000 & 3,374 & 5,682 & 30,000 \\
\hline 8 & PKR-7 & 18 & 4,000 & 218,000 & 3,374 & 5,682 & 30,000 \\
\hline 9 & KCT-1 & 15 & 1,200 & 146,000 & 1,980 & 3,183 & 20,000 \\
\hline 10 & KCT-2 & 15 & 1,200 & 146,000 & 1,980 & 3,183 & 20,000 \\
\hline 11 & KCR-1 & 17 & 2,000 & 74,904 & 1,800 & 1,589 & 35,000 \\
\hline 12 & KCR -2 & 17 & 2,000 & 74,904 & 1,800 & 1,589 & 35,000 \\
\hline 13 & KCR-3 & 17 & 2,000 & 74,904 & 1,800 & 1,589 & 35,000 \\
\hline 14 & PK-1 & 20 & 2,000 & 93,805 & 1,091 & 2,600 & 20,000 \\
\hline 15 & PK-2 & 20 & 2,000 & 93,805 & 1,091 & 2,600 & 20,000 \\
\hline 16 & FPB-1 & 18 & 2,000 & 141,600 & 1,980 & 3,183 & 20,000 \\
\hline 17 & FPB-2 & 18 & 2,000 & 141,600 & 1,980 & 3,183 & 20,000 \\
\hline 18 & BR-1 & 10 & 3,000 & 54,000 & 1,038 & 3,000 & 16,000 \\
\hline 19 & BR-2 & 10 & 3,000 & 54,000 & 1,038 & 3,000 & 16,000 \\
\hline 20 & KS-1 & 8 & 7,200 & 117,000 & 1,224 & 4,000 & 22,000 \\
\hline 21 & KS-2 & 8 & 7,200 & 117,000 & 1,224 & 4,000 & 22,000 \\
\hline
\end{tabular}

4.1. Accumulation data

Table 4.1. Supporting ship capacity

\begin{tabular}{|l|r|r|r|r|r|r|r|}
\hline \multirow{2}{*}{ No } & \multirow{2}{*}{ Nama KRI } & \multirow{2}{*}{ Speed } & \multicolumn{2}{|c|}{ Range } & \multicolumn{5}{|c|}{ Kapasitas muatan } \\
\cline { 5 - 8 } & & & (NM) & HSD (liter) & Makanan (kg) & ML (liter) & Air Tawar (liter) \\
\hline 1 & UT bantu 1 & 12 & 15,000 & $7,872,250$ & 340,000 & 38,000 & 753,000 \\
\hline 2 & UT bantu 2 & 7 & 2,160 & $4,324,387$ & 100,000 & 710,140 & $1,175,000$ \\
\hline
\end{tabular}

Table 4.2. Stricking force ship capacity.

\begin{tabular}{|c|c|c|c|c|c|c|c|}
\hline \multirow{3}{*}{ No } & \multirow{3}{*}{ Nama Kapal } & \multirow{3}{*}{ Personel } & & & & & \\
\hline & & & \multirow{2}{*}{ (liter/hari) } & \multirow[t]{2}{*}{ AT (liter/hari) } & \multirow{2}{*}{$\begin{array}{l}\text { ML } \\
\text { (liter/hari) }\end{array}$} & \multirow{2}{*}{$\begin{array}{l}\text { Bahan Kering } \\
\text { (kg/hari) }\end{array}$} & \multirow{2}{*}{\begin{tabular}{|l} 
Bahan Basah \\
(kg/hari)
\end{tabular}} \\
\hline & & & & & & & \\
\hline 1 & PKR-1 & 186 & 53,232 & 2,790 & 40 & 490 & 419 \\
\hline 2 & PKR-2 & 186 & 53,232 & 2,790 & 40 & 490 & 419 \\
\hline 4 & PKR-3 & 186 & 53,232 & 2,790 & 40 & 490 & 419 \\
\hline 5 & PKR-4 & 112 & 24,000 & 1,680 & 160 & 295 & 252 \\
\hline 6 & PKR-5 & 112 & 24,000 & 1,680 & 160 & 295 & 252 \\
\hline 7 & PKR-6 & 80 & 28,700 & 1,200 & 30 & 211 & 180 \\
\hline 8 & PKR-7 & 80 & 28,700 & 1,200 & 30 & 211 & 180 \\
\hline 9 & KCT-1 & 55 & 16,320 & 825 & 30 & 145 & 124 \\
\hline 10 & KCT-2 & 55 & 16,320 & 825 & 30 & 145 & 124 \\
\hline 11 & KCR-1 & 50 & 7,000 & 750 & 30 & 132 & 113 \\
\hline 12 & KCR -2 & 50 & 7,000 & 750 & 30 & 132 & 113 \\
\hline 13 & KCR-3 & 50 & 7,000 & 750 & 30 & 132 & 113 \\
\hline 14 & PK-1 & 67 & 15,500 & 1,005 & 120 & 125 & 151 \\
\hline 15 & PK-2 & 67 & 15,500 & 1,005 & 120 & 125 & 151 \\
\hline 16 & FPB-1 & 50 & 16,500 & 750 & 40 & 132 & 113 \\
\hline 17 & FPB-2 & 50 & 16,500 & 750 & 40 & 132 & 113 \\
\hline 18 & BR-1 & 57 & 8,987 & 855 & 20 & 107 & 128 \\
\hline 19 & BR-2 & 57 & 8,987 & 855 & 20 & 107 & 128 \\
\hline 20 & KS-1 & 34 & 6,000 & 510 & 120 & 90 & 16 \\
\hline 21 & KS-2 & 34 & 6,000 & 510 & 120 & 90 & 16 \\
\hline \multicolumn{8}{|c|}{ UT BANTU } \\
\hline 1 & UT Bantu-1 & 120 & 16,000 & 1,800 & 80 & 360 & 240 \\
\hline 2 & UT Bantu-2 & 75 & 15,000 & 1,125 & 60 & 225 & 150 \\
\hline
\end{tabular}

\subsection{Processing data with $\mathrm{GA}$.}

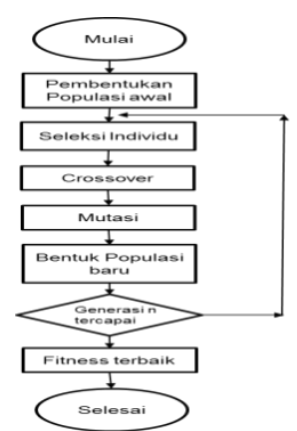

Figure 4.1. Genetic Algoritm

Table4.3. daily consumption

Tabel 4.4. Distance calculation bridgehead to the rendezvous [days]

\begin{tabular}{|c|c|c|c|c|c|c|c|c|c|}
\hline & 0 & 1 & 2 & 3 & 4 & 5 & 6 & 7 & 8 \\
\hline 0 & & 1.289 & 1.318 & 1.388 & 1.4611 & 1.095 & 1.142 & 1.202 & 1.2935 \\
\hline 1 & 1.289 & & 0.0872 & 0.1966 & 0.312 & 0.19375 & 0.1775 & 0.2088 & 0.2905 \\
\hline 2 & 1.318 & 0.0872 & & 0.1096 & 0.2256 & 0.2435 & 0.2547 & 0.1724 & 0.222 \\
\hline 3 & 1.388 & 0.1966 & 0.1096 & & 0.116 & 0.332 & 0.255 & 0.188 & 0.1694 \\
\hline 4 & 1.4611 & 0.312 & 0.2256 & 0.116 & & 0.435 & 0.3479 & 0.26 & 0.18 \\
\hline 5 & 1.095 & 0.19375 & 0.2435 & 0.332 & 0.435 & & 0.1 & 0.204 & 0.326 \\
\hline 6 & 1.142 & 0.1775 & 0.2547 & 0.255 & 0.3479 & 0.1 & & 0.105 & 0.227 \\
\hline 7 & 1.202 & 0.2088 & 0.188 & 0.188 & 0.26 & 0.204 & 0.105 & & 0.122 \\
\hline 8 & 1.2935 & 0.2905 & 0.1694 & 0.1694 & 0.18 & 0.326 & 0.227 & 0.122 & \\
\hline
\end{tabular}

Table 4.5. Minimal endurance calculation result

\begin{tabular}{|c|c|c|}
\hline UT PUKUL & endurance & Pelayanan \\
\hline 1 & 8 & 2.05 \\
\hline 2 & 5 & 0.24 \\
\hline 3 & 4 & 0.41 \\
\hline 4 & 7 & 0.68 \\
\hline 5 & 6 & 0.37 \\
\hline 6 & 8 & 0.47 \\
\hline 7 & 6 & 0.37 \\
\hline 8 & 10 & 0.25 \\
\hline
\end{tabular}

Formation of the initial population. 
Generating initial population is a process raises a number of individuals randomly or through certain procedures. Once the population size is specified, then performed the generation of the initial population. In generating initial population using permutation encoding using matlab software. The next step is to check the $S^{\prime}$ chronologically. Next is making random process that meets the capacity and time constraints. After the initial population awakened early population then check the calculated fitness value of each individual. Fitness value is used as a reference for achieving optimal value, which is looking for an individual with the greatest fitness.

\section{b. Selection.}

Selection methods using the wheel roulete which is the simplest method and is often known as stochastic sampling with replacement.

1) Calculate the fitness value of each individual

2) Calculate the probability value of each individual (Table 4.11).

3) From the probability, calculated quota of each individual in number 1-100 4) Generate a random number between 1-100 5) From the resulting number, specify which individuals are selected in the selection process.

\section{c. Crossovers}

One of the most important components in the genetic algorithm is crossovers. Crossover is a process crosses a pair of chromosomes of parents to produce offspring that would be the individual in the next generation. Offspring produced from the expected crossover inherit traits possessed by chromosome parents.

\section{d. Mutation.}

In the next step is the genes mutation. This operator serves to replace the missing genes from the population as a result of a selection process that allows the reemergence of genes that do not appear in the generation of the initial population. Mutated child chromosomes by adding a random value that is very small and low probability. Probability mutation $(\mathrm{pm})$ is the percentage of the total number of genes in a population of mutated. At this stage, using sequence-based mutation (SBM) involves two offspring crossover to mutate. Early stage, this method select randomly breaknode is a node between two subscribers in one route. If it appears twice on one route, one must be removed from service. If a customer appears in the result of mutations and appeared on the old route, the customer is removed from the old route.

\section{f. The formation of the next generation} population.

Formation of the population for the next generation based on the fitness value. Chromosome mutation and cross-over included in the next population. If you have a fitness value is smaller than the chromosome with the biggest fitness in populations in which the chromosomes descendants now be inserted into the population should be different from the existing chromosome populated.

Fitness value of the process of establishing a new population of crossover and mutation results are then compared with the fitness value of the initial population. For the fitness value of new populations smaller than the initial value of the fitness population, individuals who have a smaller fitness value which replaces the position of the population. Comparison continues until the last descendant chromosomes.

Genetic Algorithms process will continue until stopping criteria are met. Stopping criteria used is dependent on the generation achieved, if the $n$-th generation has been achieved then the genetic algorithm will stop and accept the solution as the optimal solution.

\subsection{Scenario shortest route}

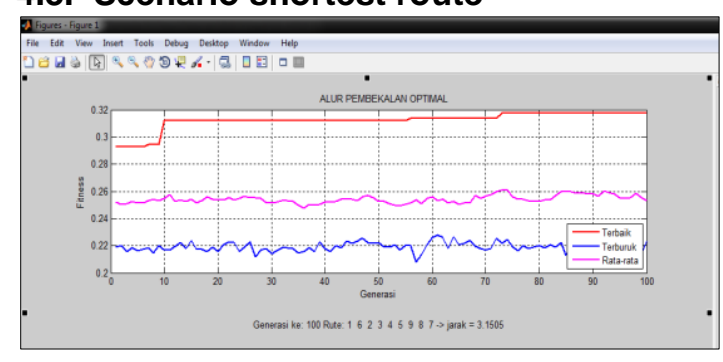




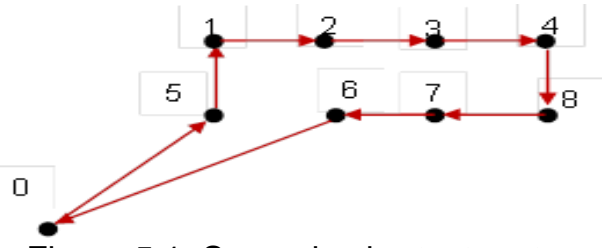

Figure 5.1. Scenario shortest route.

Genetic algorithms produce the best route is $0-5-1-2-3-4-8-7-6-0$ with a total distance of 3.1505 today. The best route is starting to show steady at genasi to 73 to the generations to 100 . It can be concluded that the best individuals survive and have already started to form. The shortest route is generated by Genetic Algorithm was used as a reference for placing the unit at which the task will receive a briefing from supporting unit.

\subsection{Skenario II}

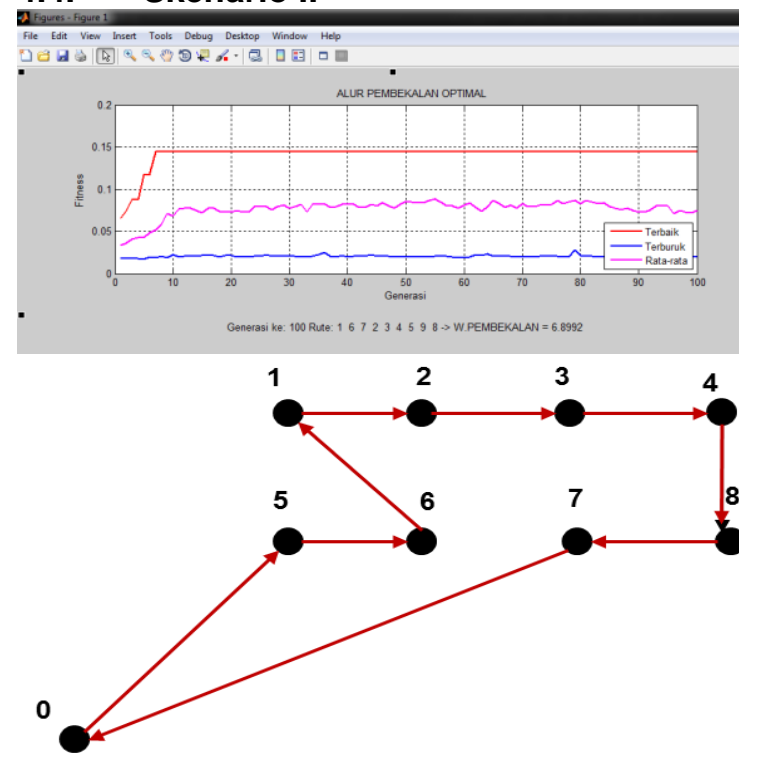

Figure 5.2. Scenario II

Results of the shortest route generated by the genetic algorithm by including a time windows and demand at any node pembekalannya is $1-6-7-2-3-4$ $-5-9-8$ with a total of 6.8992 today and the best fitness value was 0.14494 .

Results of the software running matlab shows that the best individuals began resulting in the generation to 8 . Next generation to generation 8 up to 100 showed the best stability invidu survive. This means that these generated through genetic algorithm has shown that the optimal solution.
Tablel 5.1. Replenishm distance matrix is a straight line

\begin{tabular}{|c|c|c|c|c|c|c|c|c|c|}
\hline & 1 & 2 & 3 & 4 & 5 & 6 & 7 & 8 & 9 \\
\hline 1 & 0 & 0.966204 & 0.989815 & 1.013889 & 1.044444 & 1.073611 & 1.110648 & 1.158796 & 1.19537 \\
\hline 2 & 0.966204 & 0 & 0.035093 & 0.070139 & 0.112731 & 0.151944 & 0.203796 & 0.267269 & 0.314907 \\
\hline 3 & 0.989815 & 0.035093 & 0 & 0.035093 & 0.077639 & 0.116898 & 0.168704 & 0.232176 & 0.279861 \\
\hline 4 & 1.013889 & 0.070139 & 0.035093 & 0 & 0.042593 & 0.081806 & 0.133611 & 0.19713 & 0.244769 \\
\hline 5 & 1.044444 & 0.112731 & 0.077639 & 0.042593 & 0 & 0.039259 & 0.091065 & 0.154583 & 0.202222 \\
\hline 6 & 1.073611 & 0.151944 & 0.116898 & 0.081806 & 0.039259 & 0 & 0.051852 & 0.11537 & 0.163009 \\
\hline 7 & 1.110648 & 0.203796 & 0.168704 & 0.133611 & 0.091065 & 0.051852 & 0 & 0.063519 & 0.111157 \\
\hline 8 & 1.158796 & 0.267269 & 0.19713 & 0.19713 & 0.154583 & 0.11537 & 0.063519 & 0 & 0.047639 \\
\hline 9 & 1.19537 & 0.314907 & 0.244769 & 0.244769 & 0.202222 & 0.163009 & 0.111157 & 0.047639 & 0 \\
\hline
\end{tabular}
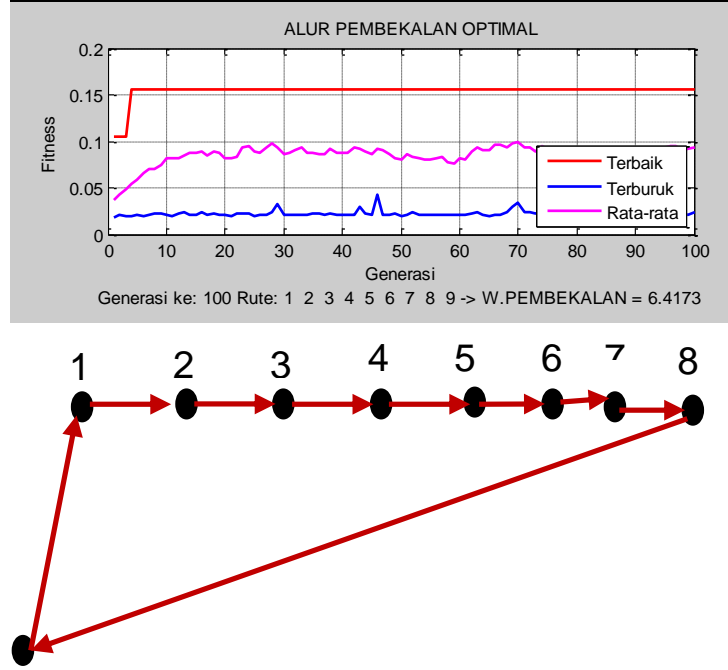

Figure 5.3. Route scenario III

Distance matrix inserted into the matlab program that has been created. The shortest route is $0-1-2-3-4-5-6-7-8-0$ by a distance of 2.4766 today. After the shortest distance is determined then the next step is to enter the time constraints in accordance with the order from the shortest route is obtained. Then the constraints of time and service time running by Genetic Algorithm with Matlab

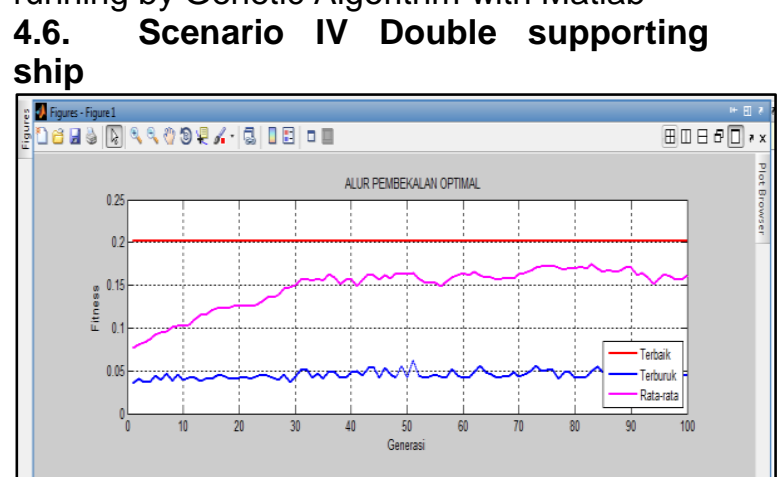

\subsection{Scenario III: The change node replenishment at sea with single supporting ship}




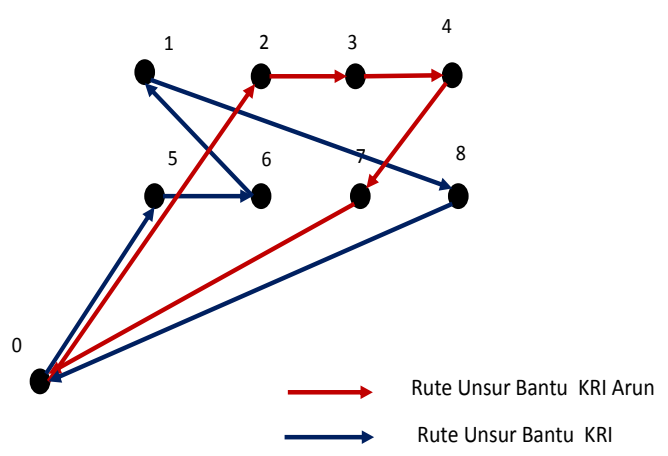

Figure 5.4. Route scenario IV.

These scenario II then restored by inserting an additional one element of auxiliary tasks. In the early stages of improvement is the inclusion of two elements inserted into the auxiliary task that has been formed in the second scenario. The next stage performs the sequence of genetic algorithms. Generated initial population of 200 population with probability cross over $=$ 0.9 and the maximum is 100 . The result generation running the genetic algorithm is a back route is changed to 1 - 6 - 7-2 - 9 - 3-4 5 - 8 with a total time of replenishm is 4,97 days of unit 8 o'clock task and the best fitness is 0.2012

4.7. Scenario $V$ The change node replenish form a straight line.
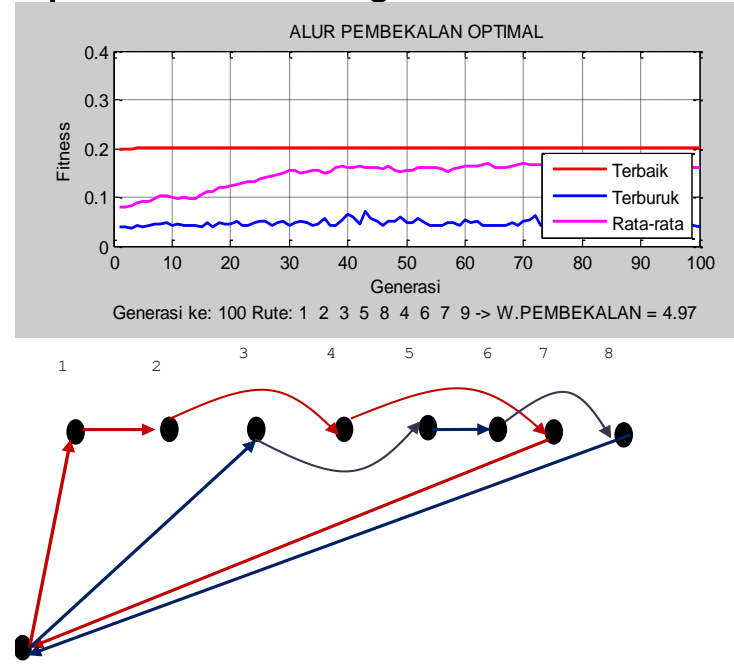

Figure 5.5. Route Skenario V

In Scenario $V$ This is the scenario when a node briefing on the fourth scenario has been known by the enemy. The alternative to change the node of replenishm as in scenario III also implemented in skenario V. However, implementation using double supporting ship is help to get the briefing time and best route is $0-1-2-4-7-3-5-6$
$-8-0$ with total time optimal replenishm was 4.97 days. The result is the same with the optimal scenario IV is 4.97 days, but the total distance is different. In scenario IV total distance of 5,962 days, while the total distance of $4.8464 \mathrm{~V}$ scenario today.

\subsection{Simulation of parameter changes Genetic Algorithm}

Of the total population parameter change is affecting the population of the many combinations of solutions are available, the larger the population the more likely genetic algorithm find the optimal solution. The more population then was only increasing computation and genetic algorithms iterations needed more in order to try all possible combinations of existing solutions. The number of population would affect the total time provisioning and optimal route.

Conclusion of the change the greater the probability of crossover is fixed and a maximum population of 100 iterations generation proved that time replenishm optimum, ie 4.97 days. For these are indeed very sensitive because it is constantly changing against the probability of crossover parameters.

To change the probability of mutation is the greater the probability of mutation, the more convergent service combinations. But for the time provisioning continued to show no change still showed optimal results is 4.97 days.

\section{CONCLUSION.}

The results of running of Genetic Algorithms can be concluded that the scheduling model has been in line with expectations, namely:

a. In scenario replenishm with single supporting ship KRI Arun obtained Route $1-6-7-2-3-4-5-9-8$ with a total waiting time at every node is 6.8992 today. The result is inefficient because there is a delay in node 2, 8 and 7 so that it can be optimized back.

b. In the scenario replenishm with double supporting unit ship KRI ARUN get the route $0-2-3-4-7-0$ and support $2 \mathrm{KRI}$ SORONG get these route $0-5-$ $6-1-8-0$. Total wait time replenish is 4,97 days in which the result is more 
optimal than the scenario with an single supporting unit ship.

C. In the scenario replenishm obtained without fighting element of the task $1 \mathrm{KRI}$ Arun 0 - 6 - 1-8 - 7 - 0 and element $2 \mathrm{KRI}$ task Sorong get the $0-5-2-3-4-0$ by the total time of the 6156 briefing.

d. In the scenario changes replenishm node gained 1 routes supporting ship $\mathrm{KRI}$ Arun 0-1-2-4-7-0 and ship $2 \mathrm{KRI}$ Sorong get the $0-3-5-6-8-$ 0 by a total of 4.97 days replenishm time and distance 4.84 days. This means that this scenario is the most optimal in terms of distance and time optimal replenishm.

e. At the change of the parameters that influence the genetic algorithm is the number of population under 30 for a total time of replenishm above 4.97 days. As for the parameters of crossover and mutation does not give effect to the total time that is optimal replenishm.

\subsection{Suggestion.}

Genetic Algorithm is an optimization method that is applied in various fields which assessed can be optimized. The key to the use of genetic algorithms is the formulation of the objective function of a case. Possibilities for further development of the application of genetic algorithm is as follows:

a. The author only develop a simple battle without involving their aircraft, marine and other defense equipment. To that can be developed for large-scale battles involving elements of aid personnel, combat aircraft Air Force, Marines and Army.

b. In this thesis, the author also does not address the real battle in the theater of operations because of the logistics amonition only under the assumption that less is so close to the reality on the ground. The next process is to estimate the process of shooting a battle with the scenario of damage from ships, aircraft and personnel involved in the fighting.

\section{REFERENCE}

[1]. Al-Khayyal, Faiz dan Hwang, SeungJune 2007. Inventory constrained maritime routing and scheduling for multi-commodity liquid bulk, Part I: Application and model, Science direct, European journal of operational research 176, pp 106-130.
[2]. Bilgen, Bilge dan Ozkarahan, Irem 2007. Mixed Integer Linear Progamming model for bulk grain blending \& shipping, International Journal Production Economics 107 pp 555-571.

[3]. Bolduc, Marei Claude, Laporte, Gilbert, Renaud, Jacques dan Boctor, Fayes F. 2010. A tabu search for split delivery vehicle routing problem with production and demand calendars. European Journal of operation research 202 pp 122-130.

[4]. Bronmo,G, Christiansen, M. dan Nygreen, B. 2007. Ship routing and scheduling with flexible cargo sizes, Journal of Operational Research Society 58, pp 1167- 1177.

[5]. Brown, G. dan Carlyle, W. M. 2008. Optimizing the US Navy's Combat Logistics Force. Naval Research Logistics, 55, pp. 800-810.

[6]. Carlatfis, Matthew, Kepaptsoglou, Konstantinos dan Sambracos, Evangelos 2009. Containership routing with time deadlines and simultaneous deliveries and pick-ups. Journal Transportation Research Part E 45, pp 210-221

[7]. Christiansen, Marielle, Fagerholt, Kjetil, Flatberg, Truls dan Haugen, Oyvind 2011. Maritime Inventory routing with multiple products: acase from cement industry. European journal of Operation Research 208 pp 86-94.

[8]. Cote,Jean-Francois dan Potvin, JeanYves 2009. A tabu search heuristic for the vehicle routing problem with private fleet and common Carier European Journal of Operational Research 198 (2009) $464-469$

[9]. Dunn, Jeffrey Scoot 1992. Scheduling underway replenishment as a generalized orienteering problem, Master Thesis, Naval Post Graduade School.

[10]. Gue, Kevin R. 2003, Dynamic distribution model for combat logistic, Science direct, Computer and Operation Research, 30, 367-381.

[11]. Hennig, F., Nygreen, B., Furman, K.C. dan Song, J., 2014. Alternatif approach to the crude oil tanker routing and scheduling problem with split pick up and delivery, European Journal of Operation Research 239, pp $1-30$

[12]. Ho, S.C. dan Haughland, D. 2004. A tabu search for the vehicle routing 
problem with time windows and split deliveries. Computers \& operation research 31 pp 1947-1964.

[13]. Laporte, Gilberte 1991, The Vehicle Routing Problem: an Overview of Exact and Approximate algoritms, European Journal of Operation Research, 59, pp 345-358

[14]. Lenhardt, Thomas A. 2006. Evaluation of a USMC combat service support logistics concept. Science direct, Mathematical and Computer Modelling 44 (2006), page 368-376.

[15]. Maras, Vladislav, Jasmina, Lazic, Davidovic, Tatjana dan Nerad, Mladenovic 2013. Routing of Barge Container Ship by Mixed Integer Programming Heuristics, Applied Soft Computing 13 pp 3515 - 3528.

[16]. Nishi, Tatsushi dan Izuno, Tsukasa 2014. Column generation heuristics for ship routing and scheduling problems in crude oil transportation with split deliveries. Science direct, Computer and chemical engineering 60, 329 338.

[17]. Rutenberg, D.C. dan Allen, J.S. 1991, The logistics of waging war: American military logistics. Air Force Logistics Management Maxwell AFB, Alabama, pp. 19-29

[18]. Santosa, Budi dan Willy, Paul. 2011, "Metoda Metaheuristik: Konsep dan Implementasi", edisi pertama, Penerbit Guna Widya, Surabaya.

[19]. Siswanto, Nurhadi, Essam, Daryl dan Sanker, Ruhul 2011. Solving the ship inventory routing and scheduling problem with undedicated compartements, Computers \& industrial Engineering 61, pp 289 - 299

[20]. Surat Keputusan Kasal Nomor: Skep/519/III/1994, tentang Pola Dasar Pembinaan Tentara Nasional Indonesia Angkatan Laut (Pum -1)

[21]. Surat Keputusan Kasal Nomor: Skep/1394/IX/2000, tentang Pola Dasar Pembinaan Bidang Logistik TNIAL (Pum -1.03)

[22]. Surat Keputusan Kasal Nomor: Skep/4943/X/1988 tanggal 31 Oktober 1988 tentang Buku Petunjuk Lapangan
Penyelengaraan Latihan Pembekalan di Laut.

[23]. Syamsi, Badrus 2002, Penerapan Algoritma Genetik untuk Meningkatkan Performansi Pengendalian PID pada Sistem Pengendalian Kecepatan Motor Induksi 3 Fase, ITS, Surabaya

[24]. Tan, K.C., Lee, L.H., Zhu,Q.L. dan Qu K. 2000, Heuristic Methode for vehicle routing problem with time windows, Science direct, Artificial Intelligence in Engineering, 15, pp 281-295.

[25]. Vidovic, Milorad, Popovic, Drazen dan Ratkovic, Branislava 2013. Mixed Integer and heuristic model for inventory routing problem in fuel delivery, Science direct, International Journal of Production Economics, pp 1 $-12$ 